\title{
Miejsca węzłowe pogranicza polsko-czeskiego jako istotne miejsca aktywizacji sieci powiązań transgranicznych
}

\section{Piotr Obracaj ${ }^{1}$, Piotr Opalka ${ }^{2}$}

\author{
${ }^{1}$ Katedra Architektury, Wydział Budownictwa, Architektury i Inżynierii Środowiska, \\ Uniwersytet Technologiczno-Przyrodniczy im. Jana i Jędrzeja Śniadeckich w Bydgoszczy, \\ e-mail: piotr.obracaj@utp.edu.pl \\ 2 Instytut Architektury i Urbanistyki, Państwowa Wyższa Szkoła Zawodowa w Nysie, \\ e-mail:opalka1@o2.pl
}

Streszczenie: $\mathrm{W}$ artykule przedstawiono badania i ich wyniki prowadzone $\mathrm{w}$ ramach transgranicznego projektu „Edu2Work” - „Współpraca między szkołami i instytucjami publicznymi na granicy czesko-polskiej w zakresie edukacji to większe szanse na rynku pracy", realizowanego w okresie od 2013 do 2015 r. Obszar badań obejmował po stronie Republiki Czeskiej okres Jesenik i Bruntal oraz po stronie polskiej powiat nyski i prudnicki. Projekt zrealizowano w ramach Programu Operacyjnego Współpracy Transgranicznej Republika Czeska - Rzeczypospolita Polska 2007-2013, realizowanego przez Katedrę Geografii Wydziału Przyrodniczego na Uniwersytecie Palackého w Ołomuńcu i Główny Instytut Górnictwa w Katowicach, przy którym w charakterze ekspertów pracowali autorzy artykułu. Praca architektów, przy udziale studentów wydziałów architektury i geografii, ukierunkowana była na badanie procesów zachodzących na pograniczu w sześciu tematach problemowych: edukacji, turystyki, transportu, sieciowania (tu: tworzenia i zagęszczania sieci łączności wszelkiej i koordynowanego współdziałania), przedsiębiorczości oraz przestrzeni i środowiska. W artykule przedstawiono przykłady działań w przestrzeni transgranicznej zwiększających integrację społeczeństw. Efektem były propozycje konkretnych rozwiązań aktywacji sieci powiązań komunikacyjnych, w których m.in. miejsca węzłowe rozumiane jako punkty przesiadkowe, w przestrzeni pogranicza powinny stanowić bazę dla rozwiązywania socjoekonomicznych i kulturowych problemów regionu.

Słowa kluczowe: pogranicze polsko-czeskie, powiązania komunikacyjne, dziedzictwo kulturowe, warsztaty projektowe.

\section{Wprowadzenie}

Następstwem przystąpienia Polski i Czech do tzw. strefy Schengen była likwidacja barier komunikacyjnych, umożliwiająca swobodę przepływu osób. Wydawałoby się iż kolejnym krokiem powinno być zbliżenie również na płaszczyźnie społecznej, gospodarczej i kulturalnej. Jednak analizując różne obszary aktywności na terenach transgranicznych, widoczne są różne prędkości i kierunki rozwoju. Nawet działania realizowane przy wsparciu programów europejskich, nie są w stanie trwale zaktywować społeczności pogranicza. Obecnie brak jest jakichkolwiek spójnych, systemowych działań w zakresie edukacji jak również mobilności na rynku pracy $[4,5]$. Próbą poszukiwania rozwiązań mających na celu jeśli nie likwidację to znaczne ograniczenie zbędnych barier był projekt „Edu2Work” - „Wspótpraca 
między szkołami i instytucjami publicznymi na granicy czesko-polskiej w zakresie edukacji to większe szanse na rynku pracy", realizowany w okresie od 2013 do 2015 r. Obszar badań obejmował po stronie Republiki Czeskiej okresy Jesenik i Bruntal oraz po stronie polskiej powiaty nyski i prudnicki. Projekt zrealizowano w ramach Programu Operacyjnego Współpracy Transgranicznej Republika Czeska - Rzeczypospolita Polska 2007-2013. Partnerami projektu była Katedra Geografii Wydziału Przyrodniczego na Uniwersytecie Palackého w Ołomuńcu i Główny Instytut Górnictwa w Katowicach. Ekspertami w zakresie turystyki i edukacji byli naukowcy z Uniwersytecie Palackého w Ołomuńcu i Alpen-Adria Universität w Klagenfurcie, natomiast badania w zakresie kształtowania przestrzeni pogranicza były prowadzone przez architektów - autorów artykułu (tabl. 1).

Dla badań szczególnie znaczącymi okazały się międzynarodowe warsztaty projektowe zorganizowane w dniach od 7 do 11 kwietnia 2014 r. w miejscowości Widnawa, tuż przy granicy polsko-czeskiej. Uczestniczyło w nich 24 studentów z Uniwersytetu Palackiego i Politechniki Opolskiej, którzy w mieszanych, czteroosobowych grupach tematycznych pod okiem ekspertów, wywodzących się z różnych środowisk akademickich, analizowali procesy zachodzące na pograniczu w sześciu tematach problemowych: edukacji, turystyki, transportu, przedsiębiorczości, sieciowania oraz przestrzeni i środowiska. Tematów nie traktowano jako autonomicznych dziedzin, lecz starano się łączyć je dla uzyskania efektu synergii. Badania były prowadzone w szerokim kontekście historycznym, w szczególności w powiązaniu z procesami społecznymi, gospodarczymi i kulturowymi. „Wspótpraca między szkołami i instytucjami publicznymi na granicy czesko-polskiej w zakresie edukacji” w celu zwiększenia szans na rynku pracy, stała się zatem pretekstem dla wieloaspektowych analiz. Tematyka projektu wpisuje się w aktualną problematykę pogranicza. Być może takie jej ujęcie da szansę obniżenia procentu bezrobocia po obu stronach granicy. Z kolei udział w projekcie czeskiej i polskiej młodzieży szkolnej i akademickiej spowoduje lepsze wzajemne poznanie się, co powinno oddziaływać na starsze pokolenia. Daje to również okazję do zaznajomienia się z możliwościami prowadzenia działalności gospodarczej po obu stronach granicy i poznanie wspólnego dziedzictwa kulturowego.

Projektowi towarzyszyły liczne interdyscyplinarne wizyty studialne w polskich i czeskich zakładach produkcyjnych (rys. 1), instytucjach i szkołach oraz warsztaty, realizowane $\mathrm{w}$ gronie różnych środowisk, $\mathrm{w}$ tym $\mathrm{z}$ organizacjami pozarządowymi i jednostkami samorządowymi, w kilkunastu miejscowościach pogranicza. Ponadto równolegle w gronie eksperckim, przy zaangażowaniu młodzieży akademickiej, analizowano procesy zachodzące na pograniczu. Ścieranie się różnych argumentów miało znaczący wpływ na lepsze zrozumienie zachodzących procesów i sformułowanie działań integrujących i aktywizujących. Istotne okazało się również zaangażowanie grup warsztatowych w działania związane z diagnozą kondycji krajobrazu transgranicznego obszaru projektowego, inspirowanie dyskusji dotyczącej możliwości rozwojowych transgranicznego rynku pracy i opracowanie atrakcyjnych wizualnie projektów odnoszących się do zadanych tematów. Wyniki badań zostały przedstawione w szerszym kontekście problematyki transgranicznego rynku pracy oraz możliwości dalszego udoskonalania zastosowanej w opisanym studium przypadku metody planistycznej. Efektem warsztatów były również propozycje działań prowadzących do zaktywowania każdego z badanych obszarów. 
Tabela 1. Obszary problemowe projektu Edu2Work oraz odpowiadające im tematy projektów warsztatowych

\begin{tabular}{|c|c|c|c|}
\hline $\begin{array}{l}\text { Obszar } \\
\text { problemowy }\end{array}$ & Temat warsztatowy & Ekspert & Członkowie grupy \\
\hline Edukacja & $\begin{array}{l}\text { Transgraniczne } \\
\text { Centrum Edukacyjne } \\
\text { (TCE) }\end{array}$ & $\begin{array}{l}\text { Dr hab. Karen Ziener, } \\
\text { Alpen-Adria } \\
\text { Universität }\end{array}$ & $\begin{array}{l}\text { Martyna Piasecka, } \\
\text { Agnieszka Duda, } \\
\text { Pavel Rochovanský, } \\
\text { Martin Turčínek }\end{array}$ \\
\hline Turystyka & $\begin{array}{l}\text { Transgraniczna Trasa } \\
\text { Turystyczna } \\
\text { (TTT) }\end{array}$ & $\begin{array}{l}\text { Dr Pavel Ptaček, } \\
\text { Palacký Universit, } \\
\text { Olomouc }\end{array}$ & $\begin{array}{l}\text { Maja Materzok, } \\
\text { Katarzyna Kolinek, } \\
\text { Jan Lukáš, } \\
\text { Ladislav Motúz }\end{array}$ \\
\hline Transport & $\begin{array}{l}\text { Zintegrowana } \\
\text { Infrastruktura } \\
\text { Transportowa } \\
\text { (ZIT w Głuchołazach }\end{array}$ & $\begin{array}{l}\text { Dr hab. inż. arch. } \\
\text { Piotr Obracaj, } \\
\text { Profesor } \\
\text { Politechniki Opolskiej }\end{array}$ & $\begin{array}{l}\text { Paulina Szarzec, } \\
\text { Sara Wojciech, } \\
\text { Mikuláš Fišer, } \\
\text { Vojtěch Kubeša }\end{array}$ \\
\hline $\begin{array}{l}\text { Przestrzeń } \\
\text { i środowisko }\end{array}$ & $\begin{array}{l}\text { Transgraniczne } \\
\text { Usługi Ekosystemowe } \\
\text { (TUE) }\end{array}$ & $\begin{array}{l}\text { Dr inż. arch. } \\
\text { Marcin Spyra, } \\
\text { Politechnika Opolska }\end{array}$ & $\begin{array}{l}\text { Michał Bartecki, } \\
\text { Dorota Michna, } \\
\text { Michael Cestr, } \\
\text { Dan Horalík }\end{array}$ \\
\hline Przedsiębiorczość & $\begin{array}{l}\text { Transgraniczny } \\
\text { Inkubator } \\
\text { Przedsiębiorczości } \\
\text { (TIP) }\end{array}$ & $\begin{array}{l}\text { Dr inż. arch. } \\
\text { Piotr Opałka, } \\
\text { Politechnika Opolska }\end{array}$ & $\begin{array}{l}\text { Emilia Szczudło, } \\
\text { Agnieszka Zając, } \\
\text { Milan Poláček, } \\
\text { Ondřej Zlámal }\end{array}$ \\
\hline Sieciowanie & $\begin{array}{l}\text { Regionalna } \\
\text { Agencja Rozwoju } \\
\text { (RAR) }\end{array}$ & $\begin{array}{l}\text { Dr Pavel Roubínek, } \\
\text { Dr Petr Kladivo, } \\
\text { Palacký Universit, } \\
\text { Olomouc }\end{array}$ & $\begin{array}{l}\text { Małgorzata Kwiatkowska, } \\
\text { Ewa Stelmach, } \\
\text { Tomáš Jurčeka, } \\
\text { Martin Štvrtecký }\end{array}$ \\
\hline
\end{tabular}

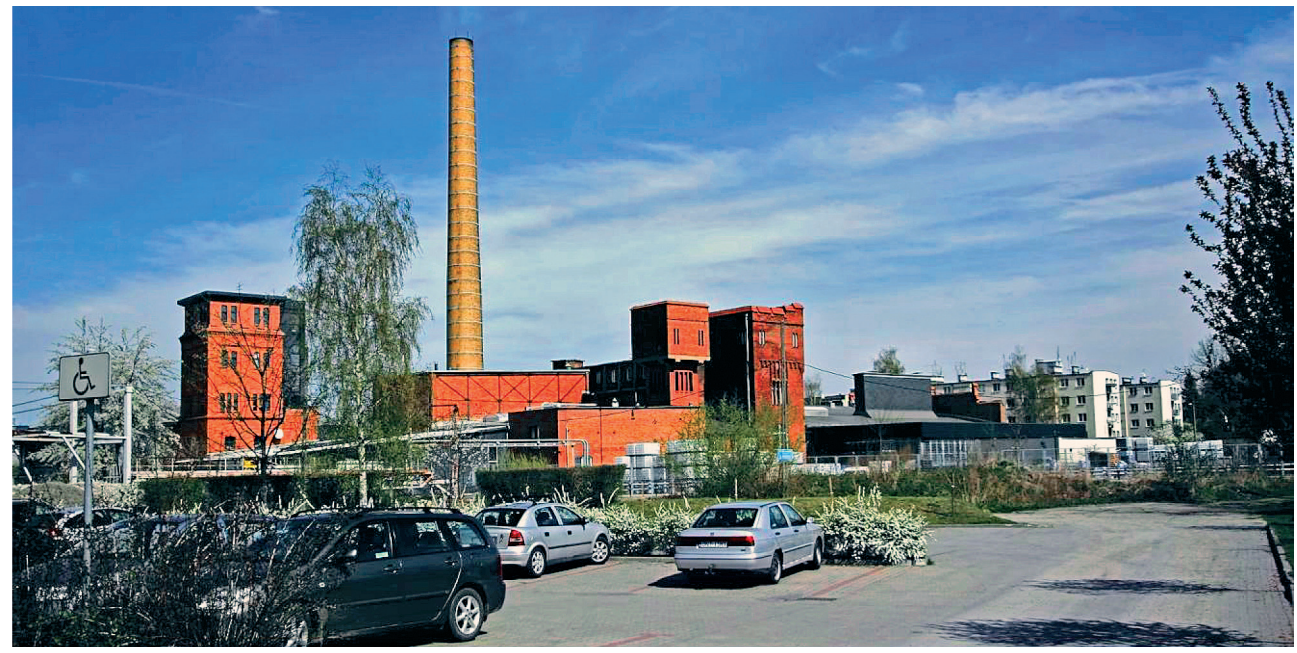

Rys. 1. Zakład Schattdecor w Głuchołazach - producent folii finish, wykorzystywanych w meblarstwie oraz projektowaniu wnętrz. Przykład udanej adaptacji tkanki historycznej. Fot. P. Obracaj (2015) 


\section{Uwarunkowania funkcjonowania pogranicza polsko-czeskiego}

\subsection{Uwarunkowania historyczne}

Zrozumienie problematyki procesów zachodzących na pograniczu, w tym także perspektywa poszukiwań rozwiązań integrujących i aktywizujących społeczności wymaga szerokiego rozpoznania tła historycznego. Badana część obszaru transgranicznego wyróżnia się na tle innych tym, iż przez ponad 500 lat funkcjonowało na niej jednolite kulturowo i gospodarczo-politycznie biskupie księstwo nyskie, stanowiące własność biskupów wrocławskich. Istotnym czynnikiem zapewniającym jego ciągłość i rozkwit był brak problemu dziedziczenia, który w ościennych księstwach prowadził do wielu konfliktów. Pomimo likwidacji księstwa w 1742 r. i jego podziale pomiędzy Prusy i Austro-Węgry, materialne dziedzictwo kulturowe po obu stronach granicy nadal jest czytelne w przestrzeni. Ustanowiona wtedy granica na rozpatrywanym obszarze w przybliżeniu przetrwała do dnia dzisiejszego [8]. Wysiedloną po 1945 r. z terenów pogranicza miejscową ludność niemiecką zastąpiła ludność napływowa, nasycona odmiennymi wzorcami kulturowymi i odniesieniami normatywnymi, która w nowych okolicznościach musiała przyjąć określone postawy. Przez kilka dekad nowe tereny były postrzegane jako tymczasowe, czego odzwierciedleniem były nieremontowane, zaniedbane gospodarstwa wiejskie. Ta niepewność miała również wpływ na określone postawy wobec sąsiada $[1,2,9]$.

Okres izolacji polsko-czechosłowackiej zakończył się wraz z upadkiem komunizmu. Lata 90. XX w. zapoczątkowały stopniowe poznawanie się społeczeństw. Dopiero wtedy, często w sposób nieformalny, zaczęto w polskich szkołach średnich wspominać o tradycjach pogranicza, głównie w obszarze turystyki i dziedzictwa kulturowego. Obecnie każde kolejne pokolenie coraz bardziej identyfikuje się z miejscem zamieszkania, co może stanowić dogodny klimat dla zbliżenia.

\subsection{Uwarunkowania spoleczno-gospodarcze}

Po minionych prawie trzech dekadach, wciąż widoczne są bariery instytucjonalne, które utrudniają swobodny przepływ na rynku pracy, oświaty czy służby zdrowia. Procesy unifikującej się Europy, w tym swobodny przepływ osób, w praktyce nie spowodowały znaczącego zbliżenia kulturowego, społecznego, gospodarczego czy ekonomicznego. W zasadzie jedynym polem aktywności jest turystyka górska, realizowana głownie na terenie czeskich Sudetów. Tereny podgórskie powiatu nyskiego i prudnickiego nie są w stanie zmienić tej asymetrii.

Budowa trwałych więzi pogranicza wymaga w pierwszym etapie identyfikacji i zbadania istniejących dysfunkcji, następnie poszukiwań rozwiązań eliminujących je oraz wprowadzających nowe wartości. Właściwa perspektywa badawcza wymaga przybliżenia sytuacji społeczno-gospodarczej mieszkańców zamieszkujących pogranicze, w tym poziomu życia mieszkańców, stopy bezrobocia, szans edukacji dzieci i młodzieży. Jej znajomość wydaje się kluczowa dla określenia zachodzących na pograniczu działań i interakcji. Porównując potencjał ekonomiczny terenów nadgranicznych należy zwrócić uwagę na wysoki stopień bezrobocia po obu stronach granicy. Okresy Bruntal i Jesenik, w dużej części obejmujące tereny położone po drugiej stronie Sudetów, od lat odnotowują największą stopę bezrobocia w całej Republice Czeskiej'

\footnotetext{
1 Wg czeskiego Ministerstwo Pracy i Spraw Socjalnych w dn. 31 marca br. największe bezrobocie odnotowano w powiatach: Karwina (9,9\%), Most (9,7\%), Jesenik (8,8\%), Ostrawa-miasto (8,5\%), Usti nad Łabą $(8,4 \%)$, Bruntal (8,3\%). W Republice Czeskiej stopa bezrobocia wyniosła 4,8\%. Na jedno wolne miejsce przypadało średnio 2,4 bezrobotnych, w tym najwięcej w powiatach: Karwina $(13,9)$, Jesenik $(10,0)$, Usti nad Łabą $(8,9)$, Sokolov (7,4), Hodonin (7,1), Znojmo (6,5), Chomutov (6,3) i Bruntal $(6,0)$. Źródło: https://www.czso.cz (data wejścia: 25.06.2017 r.). Wg danych Powiatowego Urzędu Pracy w Nysie stopa bezrobocia w powiecie nyskim w marcu br. wyniosła $12,6 \%$, przy średniej krajowej 8,1\% [11].
} 
Wśród głównych przyczyn tego stanu należy wymienić położenie na obszarze górskim i podgórskim, przez co miejscowości zlokalizowane na północ od wschodniego pasma Sudetów, Czesi określają jako odcięte od świata ${ }^{2}$. Z uwagi na izolację części czeskiego pogranicza, wynikającą z przebiegu granicy, dla ludności zamieszkującej północne pogranicze Republiki Czeskiej bliższym geograficznie obszarem są miasta polskie: Paczków, Otmuchów, Głuchołazy, Nysa i Prudnik.

\section{Tematy problemowe}

Poszczególnymi tematami zajmowały się polsko-czeskie 4 osobowe grupy studenckie pod okiem ekspertów. Efekty ich pracy dyskutowane były na ogólnym forum przy udziale przedstawicieli władz miejskich z obydwu stron granicy oraz nauczycieli ze szkół średnich ogólnokształcących, zawodowych na poziomie techników, oraz pracowników naukowo-dydaktycznych z uczelni związanych z obszarem opracowania.

\subsection{Edukacja}

Transgraniczne Centrum Edukacyjne (TCE) zaproponowane zostało jako instytucja koordynująca i korygująca działania mające na celu odpowiednie szkolenie i przebranżawianie kadr na średnim i wyższym poziomie kształcenia zawodowego. Sieć obiektów tworząca tzw. ,punkty węzłowe” miała być dogodnie skomunikowana różnymi środkami transportu. Zakładano ich lokalizację w miejscach istotnych z punktu widzenia historii i tożsamości regionalnej, co miało być ich „wartością dodaną”. Przyjęto, iż w skład TCE wchodzić będzie budynek oraz powiązany z nim system ścieżek edukacyjnych poza komunikacją kołową.

W Polsce do początku lat 90. przy większych zakładach produkcyjnych funkcjonowały szkoły zawodowe. Upadek przemysłu, przy braku działań osłonowych ze strony państwa, przypieczętował likwidację tej formy edukacji. Zlikwidowano szkoły kształcące kadry dla przemysłu ciężkiego i lekkiego. W powiecie nyskim zlikwidowano m.in. Zakłady Urządzeń Przemysłowych, Fabrykę Samochodów Dostawczych, Fabrykę Domów, Zakłady Skórzane „ASCO”. W powiecie prudnickim zamknięto Zakłady Przemysłu Bawełnianego „Frotex”. Zatem wielkokubaturowe założenia o charakterze utylitarnym i przemysłowym stały się zbędnym, trudnym do zagospodarowania balastem. I oczywiście wysoki procent praktycznie nie mierzalnego bezrobocia zaistniał nagle i szybko się powiększał. Należało szukać sposobów na przekwalifikowanie kadr. Wszelkie próby reaktywacji szkolnictwa zawodowego musiały uwzględniać elementy innowacyjności, przy czym niedobór dobrze wykształconych pracowników dla potrzeb lokalnych rynków pracy stał się ,palącym” problemem. W Czechach, państwie przede wszystkim o tradycjach przemysłowych, transformacja w kierunku nowego systemu polityczno-gospodarczego przebiegała dużo łagodniej. Przykładowo nawet w tak niewielkiej miejscowości jak Město Albrechtice liczącej zaledwie 3,5 tys. mieszkańców nadal funkcjonuje technikum rolniczo-gastronomiczne przy tylko skorygowanym pod kątem nowych potrzeb, programie nauczania. Uczniowie tej szkoły najpierw odbywają praktyki w licznych restauracjach i hotelach a później szybko znajdują zatrudnienie. Podobnie dobrze rozwinięta spółdzielczość rolnicza zasilana jest absolwentami szkół rolniczych. Elastyczność w przystosowaniu się do nowych warunków z jednej strony, a ostrożność w ,sterowaniu” kierunkami kształcenia, okazała się w praktyce skuteczna.

\footnotetext{
2 Mark Dušák w dokumencie „Nová zpráva z konce světa” („Nowy raport z końca świata”) opisuje codzienność miejscowości BílaVoda (emisja: ČT2 w dn. 20.04.2014 r.).
} 
Przedmiotowe zwiększenie współpracy między szkołami i instytucjami publicznymi na granicy czesko-polskiej w zakresie edukacji mające zwiększyć szanse na rynku pracy dotyczy przede wszystkim władz publicznych, którym podlega planowanie i zarządzanie w zakresie edukacji i legislacji. Oczywiście działania w tym obszarze powinny być skorelowane z potrzebami lokalnych rynków pracy, w tym związanych z sektorem prywatnym.

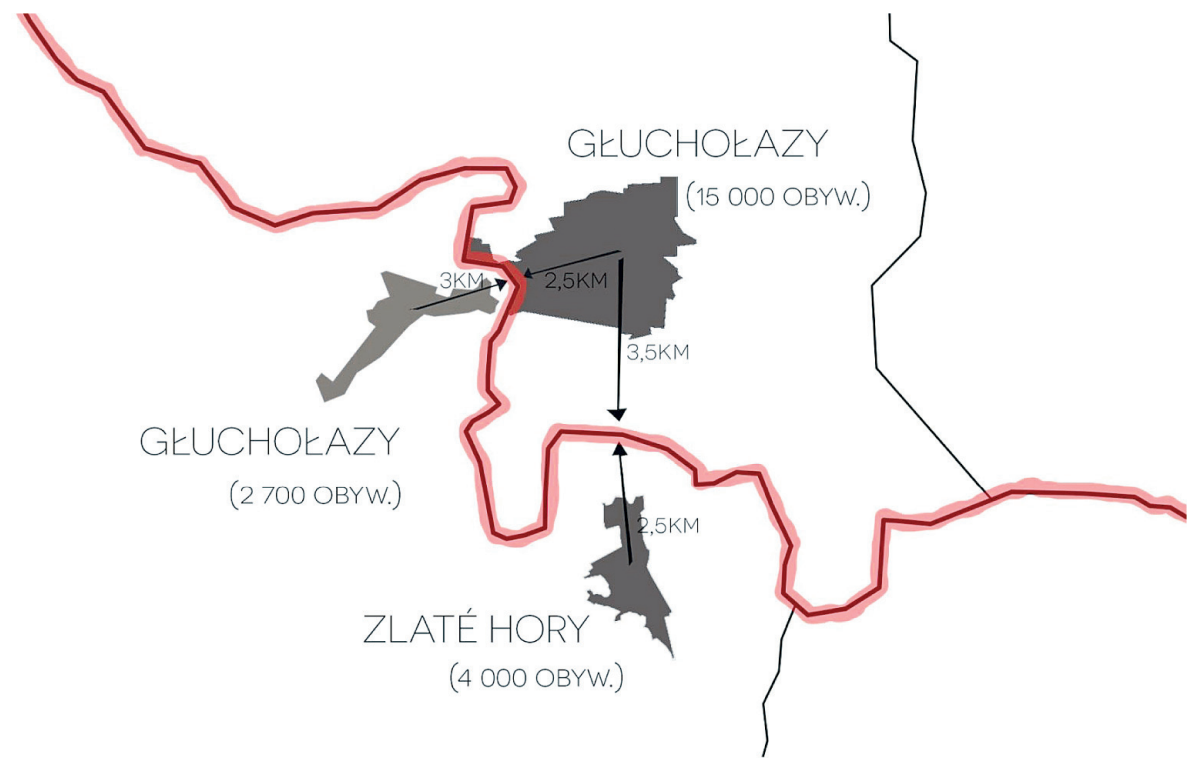

Rys. 2. Przepustowość przejść granicznych w gminie Głuchołazy [5]

\subsection{Turystyka}

Transgraniczna Trasa Turystyczna (TTT) miała tworzyć spójną sieć z Centrum Edukacyjnym (TCE). W zakresie opracowania TTT i TCE ujęto:

- przeprowadzenie analizy potencjału istniejących szlaków pieszych, rowerowych, wodnych pod kątem realizacji TTT,

- projekt koncepcyjny trasy turystyczno-widokowej z przystankami łączącej najważniejsze atrakcje turystyczne analizowanego regionu,

- projekt koncepcyjny zagospodarowania brzegów akwenów wodnych, np. jeziora nyskiego, umożliwiający organizację różnorodnych plenerowych imprez i spotkań,

- w skali urbanistycznej - zobrazowanie przebiegu trasy,

- w skali architektonicznej - zaprojektowanie punktów widokowych i towarzszących im obiektów tzw. „małej architektury”.

Centralny punkt spajający TTT, z uwagi na walory historyczne, kulturowe i krajobrazowe, zlokalizowano w Widnawie. Trasy turystyczno-widokowe oznaczono wykorzystując istniejące, ale i również projektując nowe ścieżki, w kierunkach Rychleby, Otmuchów, Łom Stachlowice, Vidnavskie Mokriny. Miejsca charakterystyczne, istotne ze względu na tradycję i historię regionu, oznakowano m.in. w formie paneli informacyjnych ${ }^{3}$ [10].

3 Por. W. Kosiński, Aktywizacja turystyczna matych miast. Aspekty architektoniczno-krajobrazowe, Kraków 2000 [3]. 


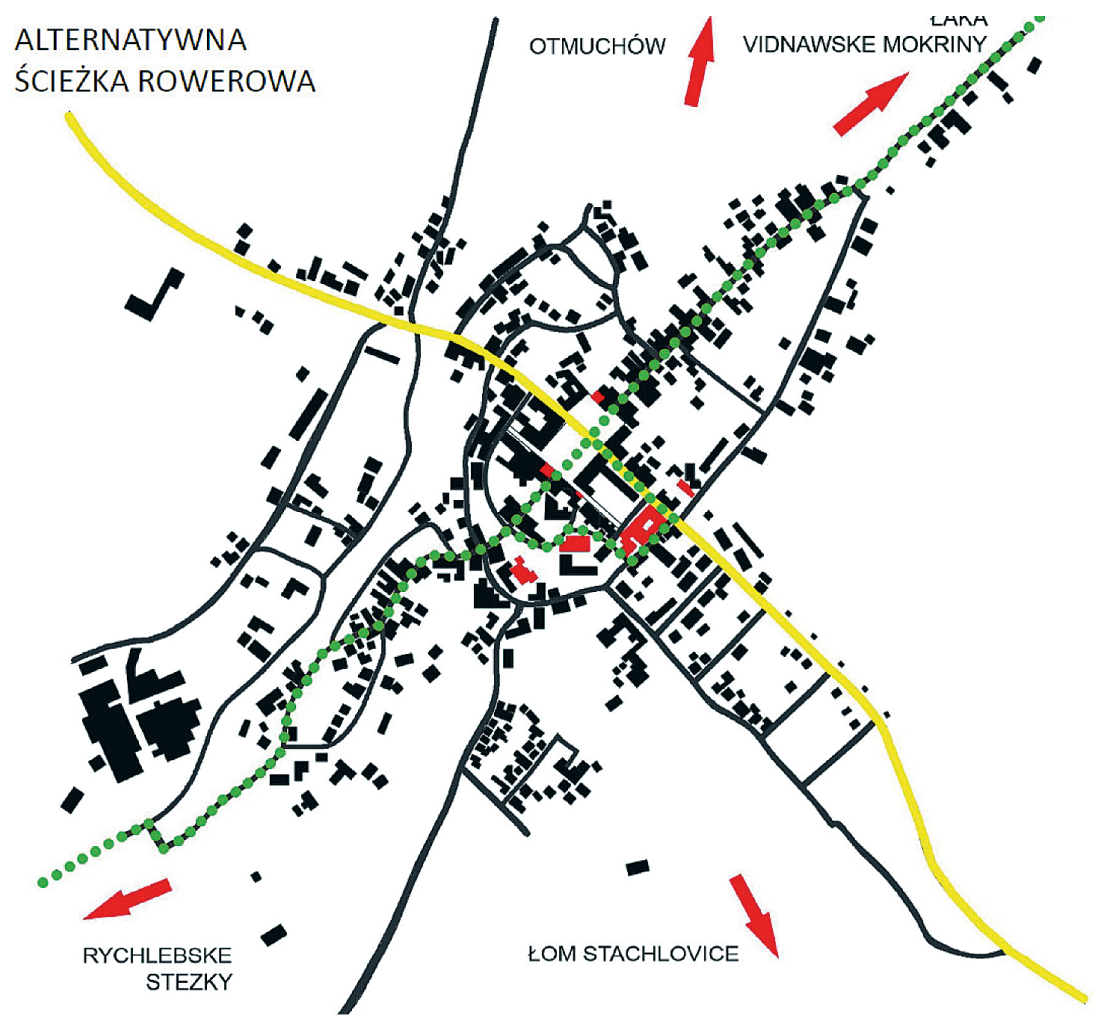

Rys. 3. Alternatywna ścieżka rowerowa w Widnawie [5]

\subsection{Transport}

Dla uzyskania efektywności w zaktywowaniu terenów pogranicza uznano za konieczną reorganizację i usprawnienie transportu, w tym w perspektywie przywrócenie kolei osobowej. Powołanie instytucji: Zintegrowana Infrastruktura Transportowa (ZIT) z ukierunkowaniem na Głuchołazy, uzasadnione jest nie tylko ze względu na położenie geograficzne miasta w obszarze rozpatrywanego pogranicza, ale również ze względu na istniejącą tam niewykorzystaną od lat, ale tylko częściowo zachowaną bazę kolejową. Faza przygotowawcza i zawierająca propozycję projektową obejmowała:

- analizę geograficzno-krajobrazową pogranicza,

- analizę urbanistyczną,

- opracowanie programu funkcjonalnego,

- opracowanie koncepcji urbanistyczno-architektonicznej ZIT w Głuchołazach.

W aspekcie planowania przestrzennego zwrócono uwagę na konieczność opracowania spójnej sieci powiązań komunikacyjnych, które w części mogłyby być realizowane na bazie zachowanej infrastruktury kolejowej (rys. 4, 5, 6, 7). Niestety przywrócenie dużej części historycznych połączeń, które do zakończenia II wojny światowej tutaj funkcjonowały, obecnie nie jest możliwe z uwagi na zniszczenie dworców kolejowych i rozebranie torowisk. Wcześniej dzięki wygodnym połączeniom komunikacyjnym możliwa była nie tylko wymiana gospodarcza. Mieszkańcy okresu jesenickiego mogli korzystać z usług nyskiego szpitala. Natomiast mieszkańcy powiatu nyskiego mogli szybciej niż obecnie dojechać koleją do 
Pragi czy Wiednia. Przemyślana reaktywacja połączeń kolejowych jako części sieci stacji przesiadkowych, mogłaby stymulować rozwój pogranicza. Miejsca węzłowe rozumiane jako punkty przesiadkowe, w przestrzeni pogranicza powinny stanowić bazę dla rozwiązywania socjoekonomicznych i kulturowych problemów regionu, przyczyniając się do bardziej zrównoważonego funkcjonowania rynku pracy, oświaty, kultury czy turystyki. Miejsca węzłowe w niegdyś spójnym kulturowo krajobrazie, istotne dla dziedzictwa kulturowego i nadal emanujące kulturowo mogłyby ponownie stanowić zaczyn dla różnych aktywności. W sposób oczywisty przemyślane, skoordynowane działania uruchomiłyby zjawisko synergii, scalające i zwiększające potencjał i atrakcyjność pogranicza.

W ramach warsztatów zaproponowano relokację dworca autobusowego w Głuchołazach w miejsce istniejącego dworca głównego, znajdującego się ok. $2 \mathrm{~km}$ od centrum miasta, przy którym obecnie funkcjonuje nieco uśpiona towarowa stacja kolejowa. Przyjęto zorganizowanie głównego centrum przesiadkowego powiązanego z kolejowym węzłem towarowym. Oddolne inicjatywy samorządowe aktywizacji sieci połączeń w zderzeniu z polityką państwowych przewoźników kolejowych póki co pozostają w sferze projektów. Od niedawna funkcjonujące połączenia kolejowe pomiędzy stacją dworca głównego a Jesenikiem czy Krnowem nie są skoordynowane z godzinami pracy ani funkcjonowania szkół. W miejscu obecnego terenu dworca autobusowego, pierwszego dużego placu przy wjeździe do Głuchołaz od strony Nysy i Prudnika, przy zachowaniu przystanku autobusowego i stacji kolejowej, zaproponowano urządzenie skweru dla mieszkańców miasta. Projektowane centrum przesiadkowe w Głuchołazach w projekcie miałoby za zadanie umożliwiać przesiadki pomiędzy pociągiem a autobusem. Przykładowo w kontekście ruchu turystycznego, turysta z Dolnego lub Górnego Śląska mógłby dojechać ze swoim rowerem do Głuchołaz, by dalej kontynuować jazdę rowerem np. w kierunku Rychlebskich Ścieżek ${ }^{4}$. Centrum potraktowano jako jedno z kluczowych elementów uzupełniających transgraniczną infrastrukturę komunikacyjną, stanowiących punkt węzłowy w koncepcji zintegrowanej sieci transportowej obszaru transgranicznego [6, 7].

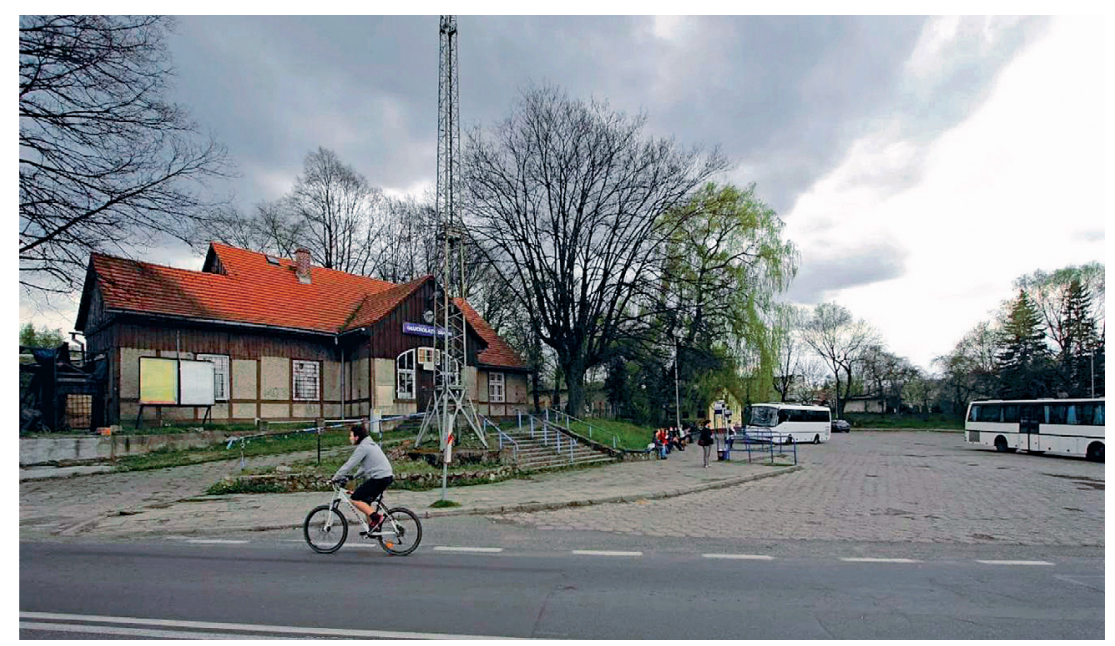

Rys. 4. Nieczynna stacja kolejowa w Głuchołazy Główne oraz dworzec PKS jako potencjalne elementy zintegrowanego systemu przesiadkowego. Fot. P. Obracaj (2015)

\footnotetext{
4 „Rychlebskie Ścieżki”, położone na południe od Widnawy, swój początek i koniec mają w miejscowości Černá Voda. Por. http://www.rychlebskestezky.cz/cs [12].
} 


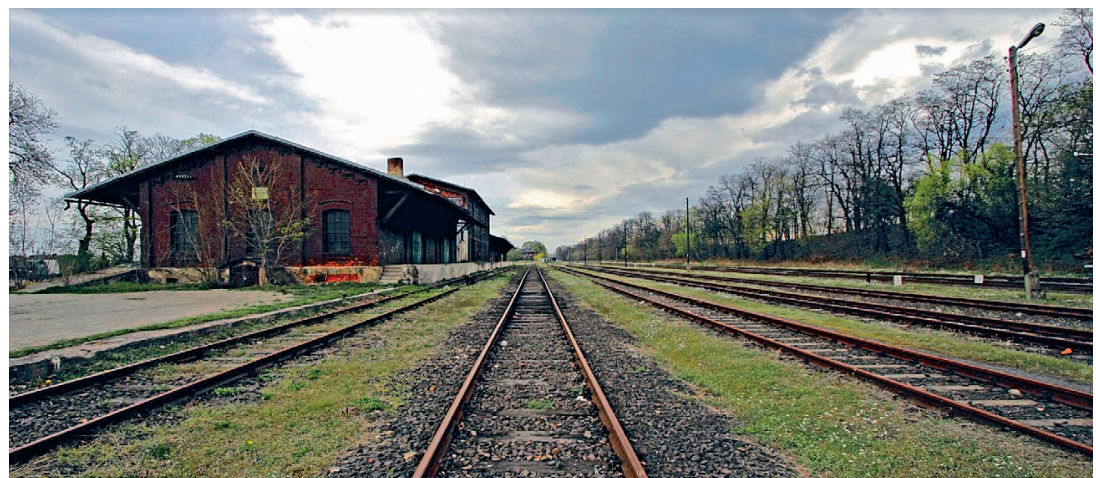

Rys. 5. Nieczynna stacja przeładunkowa przy dworcu Głównym w Głuchołazach. Fot. P. Obracaj (2015)

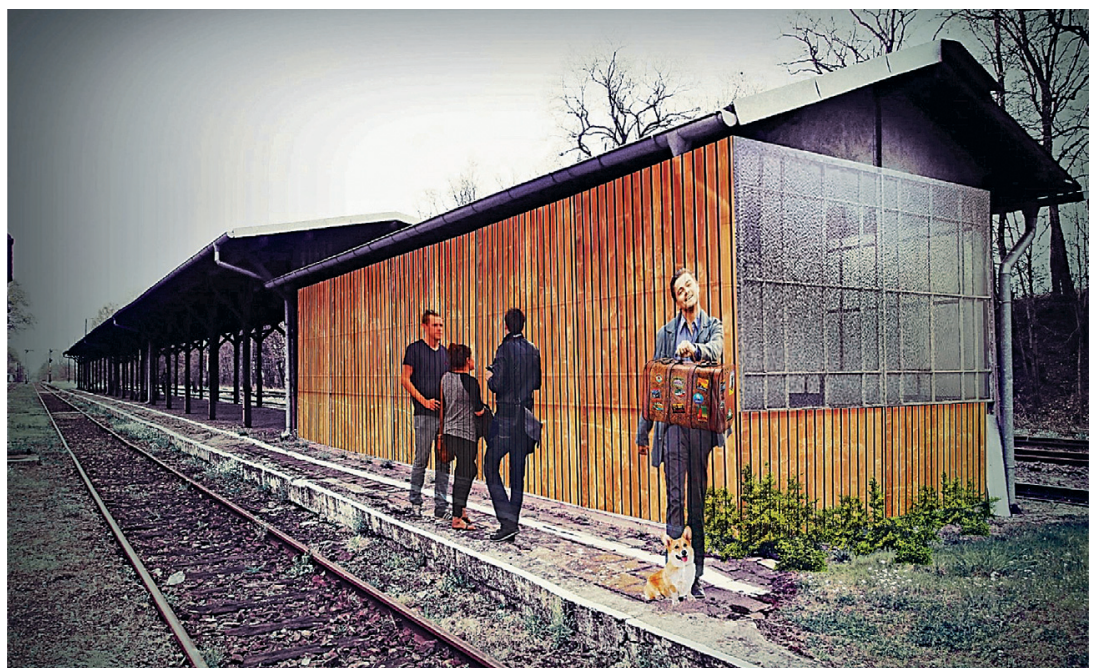

Rys. 6. Centrum przesiadkowe Głuchołazy Główne [5]

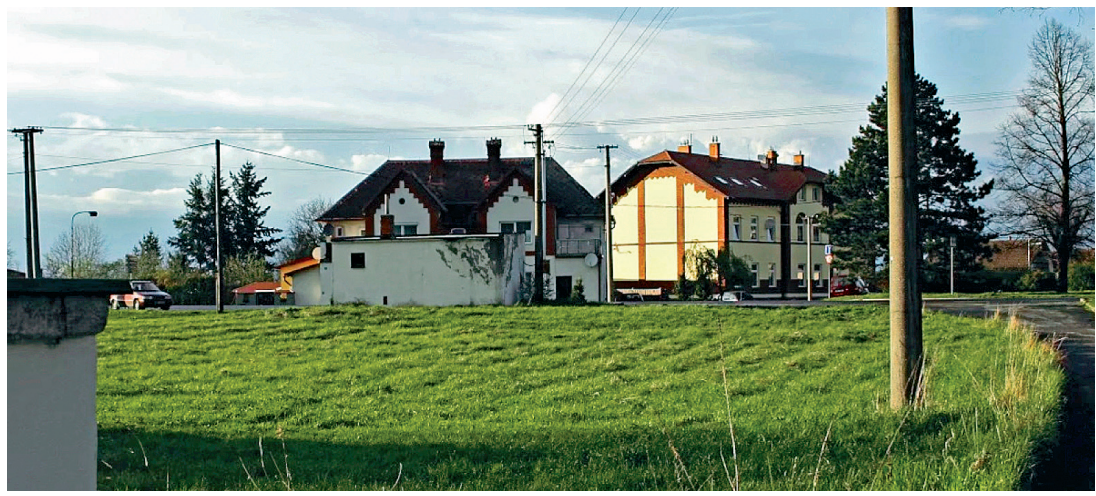

Rys. 7. Budynki przedwojennej administracji kolejowej i Wschodniej Straży Granicznej (Grenschultz Ost) w Widnawie zaadaptowane na cele mieszkalne. Fot. P. Obracaj (2015) 


\subsection{Sieciowanie}

Proponowana w ramach ,sieciowania” Regionalna Agencja Rozwoju (RAR), miałby spełniać rolę stymulatora w systemie rozwoju obszaru transgranicznego. W zakresie opracowania RAR ujęto:

- analizę funkcjonujących i możliwych do zainicjowania sieci współpracy, które mogą wejść w skład RAR,

- analizę obszaru pod kątem możliwych lokalizacji instytucji wchodzących w skład RAR,

- koncepcję funkcjonowania RAR,

- wizualizacje/ koncepcję architektoniczną obiektu (nowego lub rewitalizowanego) mieszczącego RAR.

Założono, iż RAR byłby instytucją zarządzającą i moderującą działania funkcjonujących na analizowanym obszarze sieci transgranicznych. Budując RAR sieciowanie zdefiniowano jako współpracę (w tym o charakterze międzynarodowym) na różnych poziomach, występującą głównie między instytucjami, ale mogącą zaistnieć także pomiędzy konkretnymi osobami. W wersji minimum nie ograniczono jej do instytucji posiadających odrębną osobowość prawną - przyjęto, iż jej zadaniem będzie koordynacja działań agencji rozwoju po obu stronach pogranicza.

\subsection{Przedsiębiorczość}

Kontynuacją już podjętych działań na rzecz przedsiębiorczości, są w latach 90. podjęte oddolne inicjatywy przez indywidualnych bądź grupowych przedsiębiorców po obydwu stronach granicy. Transgraniczny Inkubator Przedsiębiorczości (TIP) miałby wiązać i porząakować te inicjatywy instytucjonalnie. Zakres opracowania TIP obejmował:

- analizę obszaru pod kątem propozycji lokalizacji obiektów tworzących sieć TIP,

- opracowanie programu funkcjonalnego typowego dla TIP obiektu inkubatora,

- opracowanie koncepcji urbanistyczno-architektonicznej wybranego obiektu TIP.

Projekt TIP zakładał powstanie sieci obiektów (nowych lub adaptowanych), w których możliwe będzie prowadzenie działalności gospodarczej na preferencyjnych warunkach. Profil działalności powinien nawiązywać do specyfiki regionu transgranicznego. Projektowany obiekt będzie mógł być lokowany w środowisku kulturowym pogranicza jako nie do końca definiowana, zamknięta $\mathrm{w}$ sparametryzowanej przestrzeni forma. To obiekt powstały z powtarzalnych modułów - dla potrzeb projektu budowany jako element modułowy, na przykład w formie typowego konteneru oceanicznego (rys. 8). Materiałowo zaproponowano wykonanie modułu w szkielecie stalowym lub drewnianym i nakrytego powłoką. Warstwa epidermiczna może być wykonana z poliwęglanu, szkła lub blachy - na etapie koncepcji nie rozstrzyga się co do jej ostatecznej formy czy transparentności. Moduł będzie miał kilka wariantów wyposażenia, na przykład:

- moduł podstawowy, uniwersalny - gotowy do adaptacji w różnych konfiguracjach,

- moduł ,higieniczno-sanitarny” (lub submoduł, który można wmontować w moduł 1),

- moduł „zaplecze kuchenne” (lub submoduł, który można wmontować w moduł 1),

- moduł ,gastronomiczny”, etc.

Oczywiście nie ogranicza się ww. modułów pozostawiając ich ostateczne zdefiniowanie konkretnej technologii. Moduły będzie można układać w różnych kombinacjach, tak aby w elastyczny sposób można byłoby go zainstalować w wybranym terenie - np. terenie górskim (Sudety Wschodnie), nad jeziorem (jezioro nyskie, jezioro otmuchowskie), w strefie 
poprzemysłowej (Widnawa), w tkance urbanistycznej i ruralistycznej. Najważniejszą ideą modułu jest jego swobodne kształtowanie w terenie, w tym na przykład na wodzie (forma pomostu), jako most (łączenie dwóch dotąd izolowanych przestrzeni i sprowokowanie nowych interakcji pobudzających i ożywiających relacje społeczne). Można będzie zatem zarówno zainstalować moduły w Karlovej Studánce czy w Jeseniku (teren górski), jak również nad akwenem wodnym (jezioro nyskie). Wobec zmiennych potrzeb, nie zawsze przecież za pierwszych razem trafionych, łatwe będzie ich przenoszenie. Zatem modularność obiektów, elastyczność kształtowania i zastawiania form pozostawia ostateczny efekt przyszłym użytkownikom Jest to idea dużo bardziej trafiona niż budowanie tradycyjnego budynku, którego forma i trwałość w przestrzeni nie pozwala na cofnięcie decyzji w razie nie trafionego projektu lub jego zdezaktualizowania się lub degradacji. Studenci przeprowadzili analizy terenu obszaru pogranicza polsko-czeskiego pod kątem propozycji lokalizacji obiektów tworzących sieć TIP, w tym analizy komunikacji, która stanowi również przedmiot badań innych grup. Przedstawiono kilka propozycji obiektów TIP w konkretnej lokalizacji, po stronie czeskiej i polskiej.

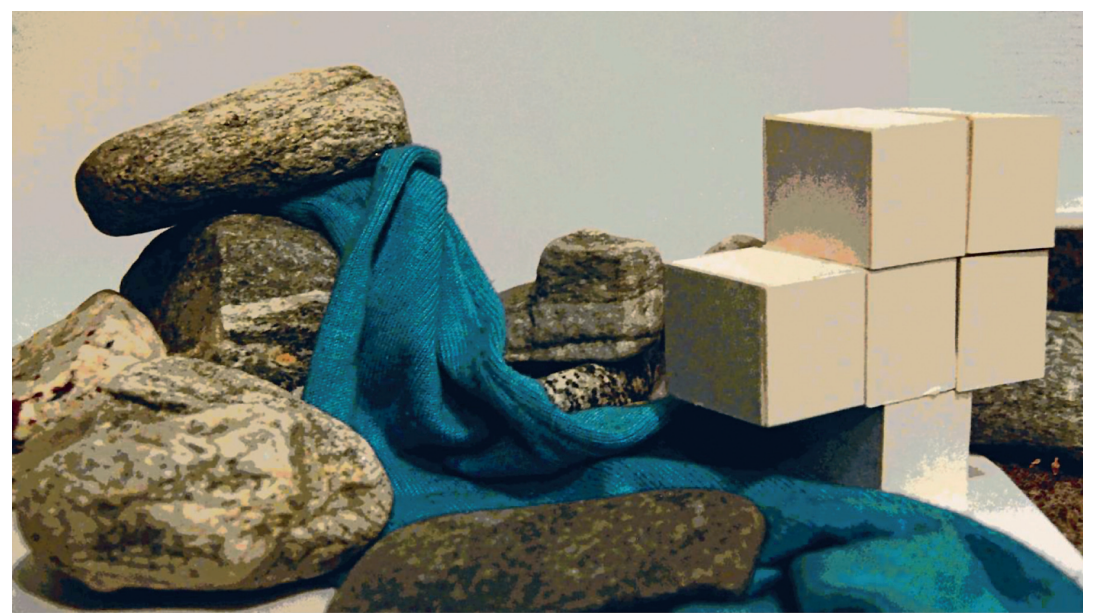

Rys. 8. Moduły TIP w środowisku kulturowym pogranicza [5]

\subsection{Przestrzeń i środowisko}

Utrzymując zasadę zrównoważonego rozwoju, tematem, który praktycznie wpisuje się pomiędzy wszystkie pozostałe jest EKOSYSTEM. Instytucja powołana jako: Transgraniczne Usługi Ekosystemowe (TUE), miałaby spełniać usługi nadrzędne w stosunku do TIT, TCE, ZIT, i RAR. W zakresie problematyki TUE za najistotniejsze uznano:

- oznaczenie i opisanie potencjału ekosystemów naturalnych i miejskich analizowanego obszaru transgranicznego,

- identyfikację obszarów wartościowych pod kątem świadczenia usług ekosystemowych,

- zidentyfikowanie i opracowanie typologii (charakterystyki) i ekosystemów zlokalizowanych na analizowanym obszarze,

- identyfikację obszarów o szczególnych wartościach przyrodniczych/ekologicznych,

- analizę możliwości odniesienia się do „usług ekosystemowych” w regionalnych dokumentach planistycznych. 
Wyniki analizy przeprowadzonej w toku prac warsztatowych wskazują na znaczącą asymetrię analizowanego krajobrazu transgranicznego. Przejawia się ona większą bioróżnorodnością ekosystemów po stronie czeskiej, a co za tym idzie ich większym potencjałem do świadczenia przez nie usług ekosystemowych. Ekosystemy po stronie polskiej charakteryzują się mniejszą bioróżnorodnością i są w większości przypadków beneficjentami usług ekosystemowych (rys. 9).Wnioski te są istotne w kontekście planowania rozwoju przestrzennego analizowanego krajobrazu transgranicznego oraz powinny zostać uwzględnione podczas jego zrównoważonego zarządzania.

Wśród szczegółowych propozycji projektowych zaproponowano m.in. zrównoważone systemy drenażu, w tym zagospodarowanie wody w miejscu powstania opadu, rozwiązania o funkcji hydrologicznej, ekologicznej i rekreacyjnej, poprzez np. wykorzystanie wody do poprawy jakości przestrzeni miejskiej (tzw. mała retencja).

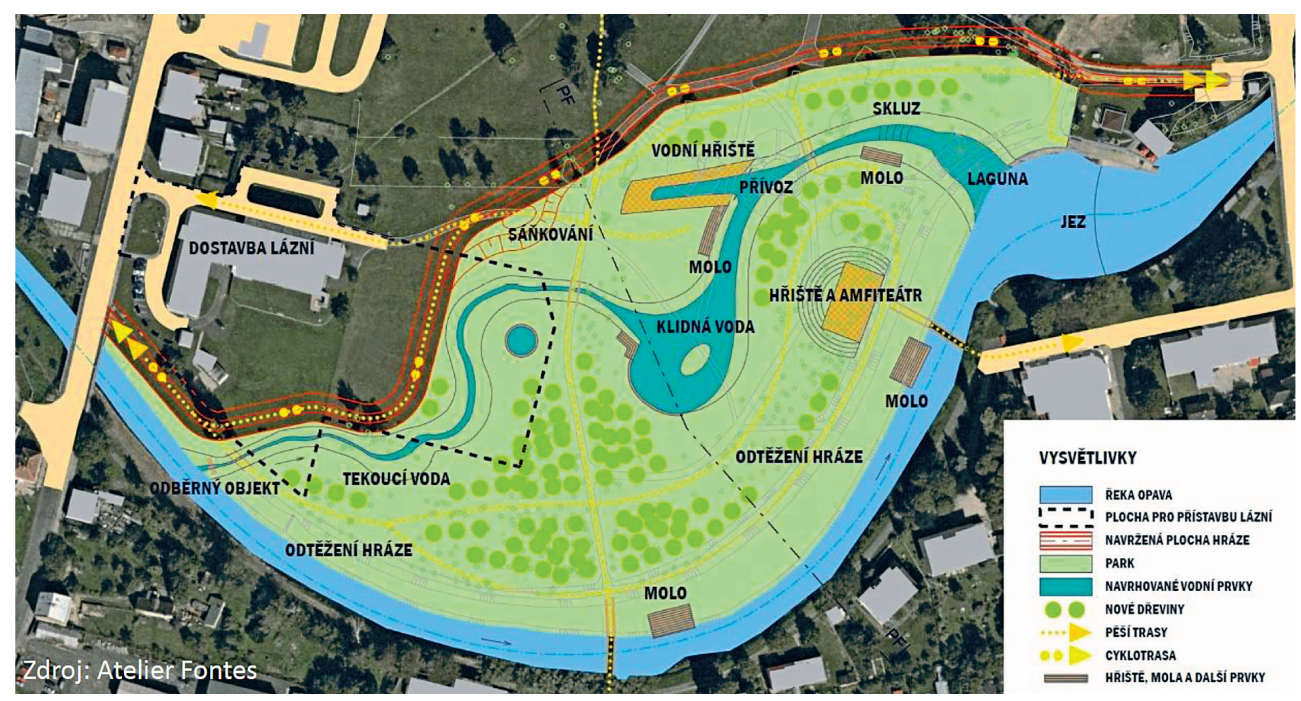

Rys. 9. Koncepcja centralnego parku w Krnowie [5]

\section{Podsumowanie}

Synergicznych, paralelnie ujawniających się efektów projektu Edu2Work, można dopatrzyć się co najmniej dwóch. Pierwszy ujawnia się w każdym z obszarów projektowo-badawczych poprzez łączenie ich podstawowych funkcji, oraz umiejętne wykorzystanie istniejących zasobów kulturowych, jak najszerzej pojętych. Drugi, to wciągnięcie do opracowania studentów, jako siły fachowej nie „skażonej” jeszcze rutyną.

Projekt Edu2Work, podobnie jak inne programy i projekty aktywujące oddolnie lokalne społeczności, ma na celu przełamywanie barier i zmianę świadomości społeczeństwa, w tym w szczególności młodego pokolenia. W dalszej perspektywie czasowej podobne działania powinny mieć wpływ na poprawę transgranicznego planowania przestrzennego. Zgromadzony materiał badawczy, diagnozę problematyki oraz szeroką dyskusję należy uznać za niezwykle wartościowe i przydatne dla dalszych prac w każdym ze środowisk, które w nim uczestniczyły. W kontekście wielu wcześniejszych projektów realizowanych na pograniczu, 
otwartym pytaniem pozostanie kwestia ich implementacji. Wciąż bowiem w relacjach polsko-czeskich widoczne są bariery, zarówno mentalne jak i wynikające z fizyczności granicy. Póki co nie są ich w stanie zlikwidować również liczne projekty unijne, które często odwołują się do idei, z którymi miejscowe społeczności do końca się nie identyfikują. Konieczne jest zatem budowanie relacji w sposób naturalny od podstaw. Dlatego fundamentem dobrej współpracy powinna być edukacja prowadzona od najwcześniejszych lat szkolnych. Zaangażowanie w projekt społeczności lokalnych oraz młodzieży szkolnej jak i akademickiej z różnych środowisk należy traktować jako konieczność dla uświadomienia wagi i komplikacji problematyki przestrzennej. Oczywiście takie działania powinny być prowadzone systematycznie i w sposób ciągły, a nie jednorazowy. Projekty unijne mogą tylko częściowo wpływać (pozytywnie) na ten stan rzeczy.

\section{Literatura}

[1] Berlińska D., Korzeniowski M. Tożsamość lokalna, regionalna, transgraniczna na pograniczu polsko-czeskim. Wydawnictwo Instytutu Śląskiego, Opole 2007.

[2] Gołdyka L. (red.) Transgraniczność w perspektywie socjologicznej. Kontynuacje. Lubuskie Towarzystwo Naukowe, Zielona Góra 1999.

[3] Kosiński W. Aktywizacja turystyczna małych miast. Aspekty architektoniczno-krajobrazowe. Wydawnictwo: Politechnika Krakowska, Monografia 269, Kraków 2000.

[4] Obracaj P. Schengen a rozwój pogranicza polsko-czeskiego [w:] Blue Notes (red. J. Kiszka), ACCENDO, 2013.

[5] Obracaj P., Opałka P., Spyra M. Czynności realizowane dla studentów uczelni w polsko-czeskim pograniczu" [w:] Uwarunkowania zrównoważonego rozwoju polsko-czeskiego obrazu transgranicznego: studium przypadku pogranicza Euroregionu Pradziad. „Geographia Moravica 4”, (red. P. Ptaček, Z. Opravil, P. Roubínek), wyd. Uniwersytet Palackého w Ołomuńcu, Ołomuniec 2015, rozdział 4, s. 105-113.

[6] Obracaj P., Opałka P. Prudnik - drogi ku naprawie tkanki miejskiej [w:] Spyra M. (red.) Transgraniczny Krajobraz Euroregionu Pradziad. Wydawnictwo: Politechnika Opolska, Opole 2013, s. $92-111$.

[7] Obracaj P., Opałka P. Wprowadzenie alternatywnej osi śródmiejskiej poprzez zagospodarowanie ciagu podwórek jako forma wykorzystania rezerwy przestrzennej [w:] Spyra M. (red.) Transgraniczny Krajobraz Euroregionu Pradziad. Wydawnictwo: Politechnika Opolska, Opole 2013, s. $112-131$.

[8] Obracaj P., Opałka P. Historyczny i kulturalny rozwój pogranicza polsko-czeskiego - powiat prudnicki i nyski [w:] Uwarunkowania zrównoważonego rozwoju polsko-czeskiego obrazu transgranicznego: studium przypadku pogranicza Euroregionu Pradziad. „Geographia Moravica 4”, (red. P. Ptaček, Z. Opravil, P. Roubínek), wyd. Uniwersytet Palackého w Ołomuńcu, Ołomuniec 2015, rozdział 4, s. 35-47.

[9] Opałka P. Etyczno-estetyczny obraz części pogranicza polsko-czeskiego [w:] Odnowa Krajobrazu Miejskiego ULAR 7. Przyszłość miast średniej wielkości (red.) N. Juzwa, A. Sulimowska-Ociepka, Wydawnictwo: Wydział Architektury Politechniki Śląskiej i Instytut Architektury i Urbanistyki Politechniki Łódzkiej, Gliwice, Łódź 2013, s. 355-360.

[10] Strategia rozwoju turystycznego pogranicza nysko-jesenickiego na obszarze powiatu nyskiego (2BA - Szkolenia i Doradztwo Strategiczne), http://powiat.nysa.pl, Nysa 2009.

[11] https://www.czso.cz (data wejścia: 25.06.2017 r.).

[12] http://www.rychlebskestezky.cz/cs (data wejścia: 25.06.2017 r.). 


\title{
Polish-Czech borderland nodal areas \\ as an important activation sites of cross-border connections networks
}

\author{
Piotr Obracaj ${ }^{1}$, Piotr Opalka ${ }^{2}$ \\ ${ }^{1}$ Faculty of Civil and Environmental Engineering and Architecture, UTP University of Science \\ and Technologyin Bydgoszcz, e-mail: piotr.obracaj@utp.edu.pl \\ ${ }^{2}$ Institute of Architecture and Urban Planning, University of Applied Sciences in Nysa, \\ e-mail:opalka1@o2.pl
}

\begin{abstract}
In this article authors present findings of their research conducted in frames of the Czech Republic - Poland cross border cooperation "Edu2Work" project "Cooperation of Czech and polish borderland schools and public institutions in the area of higher education for better chances of employability on the labor market" realized from 2013 to 2015. Scope of the research included Jesenik and Bruntal districts from Czech Republic side, as well as Nysa and Prudnik Counties from polish side. Project has been realized by the Faculty of Science/Geography of the Palacký University in Olomouc and Central Mining Institute in Katowice, under the Operational Programme of Cross Border cooperation Czech Republic Poland 2007-2013. Authors of this article have been involved to the project as experts. The work in the project, with the participation of the students, aimed at the investigating processes existing on the borderland in six thematic areas: education, tourism, transport, networking (here: creation and compaction all communication networks and cooperation coordination), entrepreneurship, space and environment.

In the article examples of some activities in the cross-border space has been presented that increase these societies integration. In result proposals of the specific solutions of the communication networks activation were introduced. They included identification of the knot locations understood as the transfer points that should become a base for socioeconomic and cultural problems of the region.
\end{abstract}

Keywords: Polish-Czech borderland, communication links, cultural heritage, design workshops. 